\title{
Hypo-cholesterolemic and hypoglycemic effects of orange albedo powder (citrus aurantium I.) on male albino rats
}

\author{
M. M. H. Osfor ${ }^{3, *}$, A. Hegazy ${ }^{1}$, Maha Abd El-moaty ${ }^{1}$, Mohammad A. Elmadbouly ${ }^{3}$, \\ A. M. R. Afify ${ }^{2}$, Amr S. M. Elbahnasawy ${ }^{1}$ \\ ${ }^{1}$ Food Science and Nutrition Department, National Research Center, Dokki, Giza, Egypt \\ ${ }^{2}$ Biochemistry Department, Faculty of Agriculture Cairo University, Giza, Egypt \\ ${ }^{3}$ Clinical Nutrition Department, Umm Al-Qura University, Saudi Arabia
}

Email address:

mosfor@yahoo.co.uk (M. M. H. Osfor)

To cite this article:

M. M. H. Osfor, A. Hegazy, Maha Abd El-moaty, Mohammad A. Elmadbouly, A. M. R. Afify, Amr S. M. Elbahnasawy. Hypo-

Cholesterolemic and Hypoglycemic Effects of Orange Albedo Powder (Citrus Aurantium L.) on Male Albino Rats, International Journal of Nutrition and Food Sciences. Vol. 2, No. 2, 2013, pp. 70-76. doi: 10.11648/j.ijnfs.20130202.17

\begin{abstract}
The present study was conducted to evaluates the hypocholesterolemic and hypoglycemic effects of dietary Orange Albedo Powder (Citrus Aurantium L.) in the hypercholesterolemic albino rats, also to examine various oxidative stress-associated with some biochemical parameters. Thirty two male albino rats weighing $110+10 \mathrm{~g}$ were divided into four groups, the first group received the basal diet only and served as (negative control), the second group received the hypercholesterolemic diet and served as (positive control), the other two groups received hypercholesterolemic diet supplemented with $10 \%, 20 \%$ orange albedo powder respectively (OrAP) for six weeks spontanously. The obtained results revealed that the groups of rats which received diets supplemented with $10 \%$ and $20 \%$ OrAP were significantly decrease total lipid, total cholesterol, triglycerides, low density lipoprotein cholesterol, liver enzymes (alanine aminotransferase, aspartate aminotransferase and alkaline phosphatase), when compared with positive control, also kidney functions were significantly improved. Body weight gain and food intake were significantly decreased when compared with positive control. The results indicate that the orange albedo is a good source of natural fiber. It could use in obese people for body loss, also serves to improve blood picture and to reduce the blood glucose level in hypercholesterolemic rats.
\end{abstract}

Keywords: Orange Albedo Powder, Hypo-Cholesterolemic, Hypoglycemic Effects

\section{Introduction}

Hyperlipidemia and hypercholesterolemia is an important risk factor for the development of atherosclerosis and coronary artery disease $(1,2)$. The main pathogenic blood parameters are increased concentrations of cholesterol bound to low-density lipoprotein (LDL-C), total blood cholesterol (T. Chol.) and triglycerides (TG). Conditions of insulin resistance such as impaired glucose tolerance or "prediabetes" are also characterized by a high risk of cardiovascular diseases (CVD) (3).

Majority of therapeutic protocols rely on drugs that belong to statin family. Statins inhibit the activity of 3hydroxy-3-methylglutaryl-CoA (HMG-CoA) reductase, which catalyzes the rate-limiting step in mevalonate bio- synthesis, a key intermediate in cholesterol metabolism. This is associated to a decrease in T. Chol. and a switch from LDL-C to high-density lipoprotein (HDL-C) fraction. Despite the significant clinical benefits provided by statins (1) many patients, in particular those with metabolic syndrome, do not achieve their recommended low-density and high-density lipoprotein (LDL, HDL) cholesterol target goals with statins (Jones, 2008). Moreover, the use of statins is forbidden in more than $40 \%$ of patients eligible for this therapeutic approach, mostly for the occurrence of side effects including muscle pain (myalgia), muscle weakness (myopathy) or liver disease in more severe cases $(4,5)$. This limits the use of statins and suggests the need of alternative therapeutic approaches.

Citrus species have been studied for medicinal properties and reported to contain numerous bioactive compounds, 
such as flavanone glycosides (narirutin, naringin, hesperidin, and neohesperidin) and natural antioxidants. Particularly, the phenolic acids have attracted more attention for their antioxidant behavior and beneficial health-promoting effects in chronic and degenerative diseases (6).

Albedo is a white, spongy and cellulosic tissue which is the principal citrus peel component. Due to its high fiber content albedo could be considered as a potential fiber source $(7,8)$.

The water-insoluble fiber-rich fraction (WIFF) derived from orange peel had very pronounced hypocholesterolemic and hypolipidemic effects. It could significantly decrease the levels of serum triglycerides, serum total cholesterol, liver total lipid, and liver cholesterol. The WIFF could be a potential cholesterol-lowering ingredient in human diets, and offer industry an opportunity to develop new formulations of fiber-rich functional foods (9). Citrus fruit byproducts could be interesting not only for its important fiber content but also because of its antioxidant capacity (10) They have a high fiber and vitamin contents as well as other associated bioactive compounds such as flavonoids and terpenes which exhibit interesting antioxidant properties (11).

The presence of functional dietary fiber and antioxidants in citrus by-products allow their application in food processing to obtain healthy products. Overall it could be interesting their incorporation in frequently consumed foods which could help to overcome the fiber deficit in actual human diet and to prevent the development of hypercholesterolemia, cancer and other diseases (12).

The objective of the present study was to evaluate the beneficial effects of orange albedo powder on rat model of diet-induced hyperlipidemia, through biochemical investigations. We try to present an overview of its potential as a technological tool to use in functional foods to reduce the incidence of cardiovascular disease through diet.

Also, to evaluate the beneficial effects of orange albedo powder as a new bread component on the value and sensitive tests of these breads.

\section{Materials and Methods}

\section{Materials:}

Fresh Orange (Citrus Aurantium L.) was obtained from local market and the Albedo was separated from the orange peels, and then dried in an hot air-oven at $45^{\circ} \mathrm{C}$ for $48 \mathrm{~h}$. The dried albedo was ground in a Multi Mill apparatus and passed through a $0.5-\mathrm{mm}$ mesh sieve to obtain a fine orange albedo powder.

\section{Chemical composition:}

The determination of moisture, crude protein, total lipid, ash and crude fibers were done, nitrogen free extract was calculated by difference, deducing the percentage of ash, crude protein, total lipid and crude fibers from 100 according to AOAC (13).

Experimental animals and diets:

Thirty two male albino rats weighing $110 \pm 10 \mathrm{~g}$ were ob- tained from the laboratory animal house, National research Center. The animals were housed individually in stainless steel cages in a controlled environment $\left(25 \pm 2{ }^{\circ} \mathrm{C}, 50-60 \%\right.$ relative humidity and 12-hour light-dark cycle). The animals were fed ad libitum with a basal diet and water for two weeks, and were then randomly assigned to 4 groups (8 rats each) as follows:

Group 1: (negative control): received basal diet which consisting of corn starch $65 \%$, casein $10 \%$, corn oil $10 \%$, salt mixture $4 \%$, vitamins mixture $1 \%$ and cellulose $10 \%$ (13).

Group 2: (positive control): received hypercholesterolemia-induced diet (high fat diet) which prepared as basal diet preparation, except that the $10 \%$ corn oil portion was replaced with $10 \%$ sheep fat and it was supplemented with $1 \%$ cholesterol and $0.25 \%$ bile salts (14).

Group 3: received $80 \%$ high fat diet plus $20 \%$ orange albedo powder.

Group 4: received 90\% high fat diet plus 10\% orange albedo powder.

\section{Experimental Design}

During the experimental period ( 6 weeks), water and diets were available ad libitum. At the end of the experiment, all the animals were scarified by cervical decapitation. Blood samples were collected in two tubes. The first one $(0.5 \mathrm{ml}$ blood on one drop of heparin solution as anticoagulants) was used for the determination of blood hemoglobin, red blood cells (RBCs), white blood cells (WBCs) and hematocrit (HCT), the 2nd tube was left for 30 minutes for coagulation and then centrifuged at $2500 \mathrm{rpm}$ at $37^{\circ} \mathrm{C}$ for $15 \mathrm{~min}$ to separate the serum which was kept in the deep freezer for the subsequent investigation. Also, body weight, food consumption were recorded day after day.

\section{Biochemical Analysis}

Lipid Profile: Cholesterol, triglycerides and total lipids " $\mathrm{mg} / \mathrm{dl}$ " were determined according to the methods of Fossati and Prencipe (15).

Liver functions tests: Aspartate aminotransferase (AST) and alanine aminotransferase (ALT) "Unit / dl" activities were measured colorimetrically at $340 \mathrm{~nm}$ in plasma according to the method described by Reitman and Frankel (16). Alkaline phosphatase (ALP) activity in plasma was determined colorimetrically at $405 \mathrm{~nm}$ according to the method of Rec (17).

Kidney functions tests: Urea "mg / dl" was determined colorimetrically at $578 \mathrm{~nm}$ according to the methods described by Patton and Crouch (18) and creatinine content "mg / dl" was carried out colorimetrically at $510 \mathrm{~nm}$ according to the methods described by Faulkner and King (19).

Determination of glucose: Plasma glucose level was determined colorimetrically at $510 \mathrm{~nm}$ according to Trinder (20).

Determination of total protein and albumin: Plasma total protein and plasma albumin were determined colorimetrically according to the methods described by Henry (21) and Doumas and Peters (22) respectively. 
Blood picture: The concentration of blood hemoglobin, Red blood cells (R.B.Cs), White blood cells (W.B.Cs) and hematocrite (HCT) were determined colorimetrically at 546 $\mathrm{nm}$ according to the method of International Committee for Standardization in Haematology (23); Natt and Herrick (24) and Campbell (25) respectively.

Statistical analysis: Statistical analysis (standard deviation "SD" and standard error "SE") was carried out according to Fisher (26). LSD (Least significant difference) test was used to compare the significant differences between means of treatment (27). The statistical package for social science S.P.S.S. (28) program version was used for all analysis.

\section{Results}

Table 1. Chemical composition of Orange Albedo as $(\mathrm{g} / 100 \mathrm{~g})$ dry weight basis.

\begin{tabular}{lllllll}
\hline Sample & $\begin{array}{l}\text { Moisture } \\
\text { (Air dry) }\end{array}$ & $\begin{array}{l}\text { Crude } \\
\text { protein }\end{array}$ & $\begin{array}{l}\text { Total } \\
\text { lipid }\end{array}$ & Ash & $\begin{array}{l}\text { Crude } \\
\text { fiber }\end{array}$ & $\begin{array}{l}\text { Nitrogen } \\
\text { free extract }\end{array}$ \\
\hline $\begin{array}{l}\text { Orange } \\
\text { Albedo }\end{array}$ & 19.9 & 7.26 & 0.2 & 2.30 & 9.92 & 80.32 \\
\hline
\end{tabular}

Moisture of fresh Orange Albedo was $72.6 \%$.

Table 2. The mean value of Body Weight Gain, Feed Efficiency Ratio and Food Intake in the experimental rats (mean $+S$. E.).

\begin{tabular}{llll}
\hline $\begin{array}{l}\text { Parameters } \\
\text { Treatments }\end{array}$ & $\begin{array}{l}\text { Body Weight } \\
\text { Gain (g/d) }\end{array}$ & FER & $\begin{array}{l}\text { Food intake } \\
\text { (g/d) }\end{array}$ \\
\hline $\begin{array}{l}\text { G-1 (Negative } \\
\text { Control) }\end{array}$ & $1.3 \pm 0.11 \mathrm{c}$ & $0.07 \pm 0.00 \mathrm{c}$ & $18.0 \pm 0.60 \mathrm{~b}$ \\
$\begin{array}{l}\text { G-2 (Positive } \\
\text { Control) }\end{array}$ & $2.4 \pm 0.06 \mathrm{a}$ & $0.12 \pm 0.00 \mathrm{a}$ & $20.1 \pm 0.33 \mathrm{a}$ \\
G-3 $(20 \%$ OrAP) & $1.4 \pm 0.07 \mathrm{c}$ & $0.09 \pm 0.00 \mathrm{~b}$ & $14.3 \pm 0.65 \mathrm{c}$ \\
G-4 $(10 \%$ OrAP) & $1.8 \pm 0.06 \mathrm{~b}$ & $0.12 \pm 0.00 \mathrm{a}$ & $14.8 \pm 0.66 \mathrm{c}$ \\
\hline
\end{tabular}

Means with different letters are significantly different $(p<0.05)$

Table 3. Plasma total lipid, total cholesterol, triglycerides, $L D L-C, H D L-$ $C(\mathrm{mg} / \mathrm{dl})$ and $A I$ in the experimental rats (mean $+S$. E.).

\begin{tabular}{|c|c|c|c|c|c|c|}
\hline $\begin{array}{l}\text { Parameters } \\
\text { Treatments }\end{array}$ & $\begin{array}{l}\text { Total } \\
\text { Lipid } \\
\text { (mg/dl) }\end{array}$ & $\begin{array}{l}\text { Total } \\
\text { Cholesterol } \\
(\mathrm{mg} / \mathrm{dl})\end{array}$ & $\begin{array}{l}\text { Triglycerides } \\
\text { (mg/dl) }\end{array}$ & $\begin{array}{l}\text { sLDL-C } \\
(\mathrm{mg} / \mathrm{dl})\end{array}$ & $\begin{array}{l}\text { HDL-C } \\
(\mathrm{mg} / \mathrm{dl})\end{array}$ & AI \\
\hline $\begin{array}{l}\text { G-1 } \\
\text { (Negative } \\
\text { Control) }\end{array}$ & $\begin{array}{l}631 \\
\pm 38.1 \mathrm{~b}\end{array}$ & $\begin{array}{l}199 \\
\pm 6.2 \mathrm{~b}\end{array}$ & $\begin{array}{l}124 \\
\pm 7.6 \mathrm{~b}\end{array}$ & $\begin{array}{l}140 \\
\pm 3.4 \mathrm{~b}\end{array}$ & $\begin{array}{l}48.4 \\
\pm 3.0 \mathrm{~b}\end{array}$ & 3.11 \\
\hline $\begin{array}{l}\text { G-2 } \\
\text { (Positive } \\
\text { Control) }\end{array}$ & $\begin{array}{l}1252 \\
\pm 36.5 \mathrm{a}\end{array}$ & $\begin{array}{l}388.9 \\
\pm 11.8 \mathrm{a}\end{array}$ & $\begin{array}{l}395 \\
\pm 17.2 \mathrm{a}\end{array}$ & $\begin{array}{l}324 \\
\pm 11.5 \mathrm{a}\end{array}$ & $\begin{array}{l}37.8 \\
\pm 3.5 \mathrm{c}\end{array}$ & 9.28 \\
\hline $\begin{array}{l}\text { G-3 } \\
(20 \% \text { OrAP })\end{array}$ & $\begin{array}{l}557 \\
\pm 30.4 b\end{array}$ & $\begin{array}{l}184 \\
\pm 5.3 \mathrm{~b}\end{array}$ & $\begin{array}{l}90 \\
\pm 3.6 \mathrm{c}\end{array}$ & $\begin{array}{l}103 \\
\pm 3.8 \mathrm{c}\end{array}$ & $\begin{array}{l}59.3 \\
\pm 1.9 \mathrm{a}\end{array}$ & 2.10 \\
\hline $\begin{array}{l}\text { G-4 } \\
(10 \% \text { OrAP) }\end{array}$ & $\begin{array}{l}615 \\
\pm 28.4 \mathrm{~b}\end{array}$ & $\begin{array}{l}196 \\
\pm 5.1 \mathrm{~b}\end{array}$ & $\begin{array}{l}116 \\
\pm 3.53 \mathrm{bc}\end{array}$ & $\begin{array}{l}118 \\
\pm 3.8 \mathrm{c}\end{array}$ & $\begin{array}{l}50.3 \\
\pm 1.9 \mathrm{~b}\end{array}$ & 2.90 \\
\hline
\end{tabular}

Means with different letters are significantly different $(p<0.05)$.
Table 4. Plasma protein, albumin $(\mathrm{g} / \mathrm{dl})$ and plasma glucose $(\mathrm{mg} / \mathrm{dl})$ of the experimental rats (mean $+S$. E.).

\begin{tabular}{|c|c|c|c|}
\hline & $\begin{array}{l}\text { Total Protein } \\
\text { (g/dl) }\end{array}$ & Albumin (g/dl) & Glucose (mg/dl) \\
\hline $\begin{array}{l}\text { G-1 } \\
\text { (Negative } \\
\text { Control) }\end{array}$ & $7 \pm 0.26 \mathrm{a}$ & $4 \pm 0.28 \mathrm{a}$ & $87 \pm 6.67 b$ \\
\hline $\begin{array}{l}\text { G-2 } \\
\text { (Positive } \\
\text { Control) }\end{array}$ & $4.2 \pm 0.28 \mathrm{c}$ & $2.5 \pm 0.24 b$ & $105 \pm 3.95 \mathrm{a}$ \\
\hline $\begin{array}{l}\text { G-3 } \\
(20 \% \text { OrAP })\end{array}$ & $7.2 \pm 0.24 \mathrm{a}$ & $3.9 \pm 0.31 \mathrm{a}$ & $85.5 \pm 3.89 b$ \\
\hline $\begin{array}{l}\text { G-4 } \\
(10 \% \text { OrAP) }\end{array}$ & $5.8 \pm 0.21 b$ & $2.8 \pm 0.23 b$ & $88.1 \pm 3.57 b$ \\
\hline
\end{tabular}

Means with different letters are significantly different $(p<0.05)$.

Table 5. Complete blood picture of the experimental rats (mean + S. E.).

\begin{tabular}{lllll}
\hline $\begin{array}{l}\text { Parameters } \\
\text { Treatments }\end{array}$ & $\begin{array}{l}\text { Hemoglobin } \\
(\mathbf{g} / \mathbf{d l})\end{array}$ & $\begin{array}{l}\text { RBCs } \\
\text { Count } \\
(\times \text { million } \\
\left.\text { cells } / \mathbf{m m}^{3}\right)\end{array}$ & $\begin{array}{l}\text { Hematocrit } \\
\text { Value } \\
(\text { HCT \%) }\end{array}$ & $\begin{array}{l}\text { WBCs } \\
\text { Count }\left(\times \mathbf{1 0}^{3}\right. \\
\text { cells } / \mu \mathbf{L})\end{array}$ \\
\hline $\begin{array}{l}\text { G-1 } \\
\text { (Negative } \\
\text { Control) }\end{array}$ & $11.2 \pm 0.55 \mathrm{a}$ & $5.2 \pm 0.17 \mathrm{a}$ & $36.9 \pm 2.02 \mathrm{a}$ & $9.6 \pm 0.84 \mathrm{a}$ \\
$\begin{array}{l}\text { G-2 } \\
\text { (Positive }\end{array}$ & $9.3 \pm 0.55 \mathrm{~b}$ & $3.6 \pm 0.18 \mathrm{~b}$ & $29.1 \pm 1.03 \mathrm{~b}$ & $3.3 \pm 0.24 \mathrm{~d}$ \\
Control) & & & & \\
& & & & \\
$\begin{array}{l}\text { G-3 } \\
(20 \% \text { OrAP) }\end{array}$ & $12.7 \pm 0.64 \mathrm{a}$ & $4.9 \pm 0.27 \mathrm{a}$ & $38.9 \pm 1.93 \mathrm{a}$ & $6.8 \pm 0.63 \mathrm{~b}$ \\
$\begin{array}{l}\text { G-4 } \\
(10 \% \text { OrAP) }\end{array}$ & $11.7 \pm 0.42 \mathrm{a}$ & $4.2 \pm 0.19 \mathrm{~b}$ & $34.8 \pm 1.73 \mathrm{a}$ & $5.0 \pm 0.24 \mathrm{c}$ \\
\hline
\end{tabular}

Means with different letters are significantly different $(p<0.05)$.

Table 6. Plasma ALT, AST and ALP activities (IU/L) in the experimental rats (mean $+S$. E.).

\begin{tabular}{lccc}
\hline Parameters & AST (IU/L) & ALT (IU/L) & ALP (IU/L) \\
\hline $\begin{array}{l}\text { G-1 } \\
\text { (Negative }\end{array}$ & $28.4 \pm 2.32 \mathrm{~b}$ & $25.6 \pm 2.25 \mathrm{~b}$ & $91 \pm 4.81 \mathrm{~b}$ \\
Control) & & & \\
$\begin{array}{l}\text { G-2 } \\
\text { (Positive }\end{array}$ & $93.1 \pm 6.42 \mathrm{a}$ & $86 \pm 4.04 \mathrm{a}$ & $183 \pm 4.25 \mathrm{a}$ \\
Control) & & & \\
$\begin{array}{l}\text { G-3 } \\
(20 \% \text { OrAP) }\end{array}$ & $27.9 \pm 3.21 \mathrm{~b}$ & $32.8 \pm 3.62 \mathrm{~b}$ & $82.1 \pm 6.6 \mathrm{~b}$ \\
$\begin{array}{l}\text { G-4 } \\
(10 \% \text { OrAP) }\end{array}$ & $30.3 \pm 3.23 \mathrm{~b}$ & $32.1 \pm 3.48 \mathrm{~b}$ & $87.3 \pm 6.5 \mathrm{~b}$ \\
\hline
\end{tabular}

Means with different letters are significantly different $(p<0.05)$. 
Table 7. Plasma urea and creatinine $(\mathrm{mg} / \mathrm{dL})$ of the experimental rats $($ mean + S. E.).

\begin{tabular}{lll}
\hline $\begin{array}{l}\text { Parameters } \\
\text { Treatments }\end{array}$ & Urea $(\mathbf{m g} / \mathbf{d L})$ & Creatinine $(\mathbf{m g} / \mathbf{d L})$ \\
\hline $\begin{array}{l}\text { G-1 } \\
\text { Negative }\end{array}$ & $26.6 \pm 3.1 \mathrm{a}$ & $0.9 \pm 0.08 \mathrm{~b}$ \\
$\begin{array}{l}\text { Control) } \\
\text { G-2 } \\
\text { (Positive }\end{array}$ & $12.9 \pm 1.73 \mathrm{~b}$ & $1.2 \pm 0.07 \mathrm{a}$ \\
$\begin{array}{l}\text { Control) } \\
\text { G-3 } \\
(20 \% \text { OrAP) }\end{array}$ & $28.6 \pm 2.73 \mathrm{a}$ & $0.9 \pm 0.06 \mathrm{~b}$ \\
$\begin{array}{l}\text { G-4 } \\
(10 \% \text { OrAP) }\end{array}$ & $19.1 \pm 1.68 \mathrm{~b}$ & $1.2 \pm 0.06 \mathrm{a}$ \\
\hline
\end{tabular}

Means with different letters are significantly different $(p<0.05)$.

Table 8. Relative organs weight (g) of the experimental rats (mean $+S$. E.).

\begin{tabular}{|c|c|c|c|c|}
\hline $\begin{array}{l}\text { Organs } \\
\text { Treatments }\end{array}$ & Liver & Heart & Kidney & Spleen \\
\hline $\begin{array}{l}\mathrm{G}-1 \\
\text { (Negative } \\
\text { Control) }\end{array}$ & $9.1 \pm 0.27 \mathrm{~d}$ & $1.3 \pm 0.06 \mathrm{a}$ & $2.2 \pm 0.05 \mathrm{c}$ & $1.1 \pm 0.05 \mathrm{a}$ \\
\hline $\begin{array}{l}\text { G-2 } \\
\text { (Positive } \\
\text { Control) }\end{array}$ & $20.0 \pm 0.85 a$ & $1.4 \pm 0.05 \mathrm{a}$ & $2.7 \pm 0.06 \mathrm{a}$ & $1.3 \pm 0.06 \mathrm{a}$ \\
\hline $\begin{array}{l}\text { G-3 } \\
(20 \% \text { OrAP) }\end{array}$ & $11.6 \pm 0.77 \mathrm{c}$ & $1.4 \pm 0.06 \mathrm{a}$ & $2.4 \pm 0.06 \mathrm{bc}$ & $1.2 \pm 0.03 \mathrm{a}$ \\
\hline $\begin{array}{l}\text { G-4 } \\
(10 \% \text { OrAP) }\end{array}$ & $15.1 \pm 0.62 b$ & $1.4 \pm 0.06 \mathrm{a}$ & $2.5 \pm 0.09 \mathrm{ab}$ & $1.2 \pm 0.05 \mathrm{a}$ \\
\hline
\end{tabular}

Means with different letters are significantly different $(p<0.05)$.

\section{Discussion}

The chemical composition of orange albedo powder was shown that it is rich in dietary fibers $(9.92 \%)$ dry weight basis. These results agree with Chau and Huang (29) who reveal that the peel of orange possesses a high level of water-insoluble fiber-rich fraction (WIFF) which has distinctive physicochemical properties for food applications.

The increased in BWG, FI and FER for positive control which fed on hypercholesterolemic diet may be due to the presence of animal fat and cholesterol used to increase feeding. These results agree with Milagro et al. (30) who reported that animals fed on the high fat diet showed higher body weight, fat deposition and total liver weight and increased energy intake compared with those on the standardfat diet. Also the results revealed that the reduction in BWG of the rats fed on diet containing $20 \%$ OrAp, indicate muscle tissue wasting as a result of the reduction in food consumption which may due to high fiber content in OrAp at the high level intake. Also, Pectin in orange peel can also help diminish an overactive appetite, which may lead to unwanted weight gain. In the present study, the rats fed on hypercholesterolemic diet (positive control) showed in- creased total lipid, total cholesterol (TC), triglycerides (TG) and LDL-C, and decreased HDL-C. Meanwhile, groups supplemented with 10 and $20 \%$ OrAP alleviated the increase in TC, TG, total lipid and LDL-C and resulted in increasing HDL-C. Lowering levels of total lipid, TC, LDL-C and improving level of HDL-C has been linked to a lower risk of coronary heart disease (CHD) (30).

Chau et al. (9) demonstrates that the WIFF derived from Orange peel had very pronounced hypocholesterolemic and hypolipidemic effects as compared to cellulose. It could significantly decrease the levels of serum triglycerides, serum total cholesterol, liver total lipid, and liver cholesterol. The hypocholesterolemic action of WIFF is due to its ability to enhance cholesterol and bile acids excretion. WIFF could be a potential cholesterol-lowering ingredient in human diets, and offer industry an opportunity to develop new formulations of fiber-rich functional foods.

Pectin, the dietary fiber that is so effective in helping to reduce cholesterol, is present in large amounts in the white lining of citrus fruit (albedo). An easy way to increase pectin intake is to eat the white pith. Pectin is a major component of the kind of fiber that is known to lower cholesterol. Pectin is also helpful in stabilizing blood sugar. A single orange provides 3 grams of fiber, and dietary fiber has been associated with a wide range of health benefits (31).

The improvement in lipid profile of blood could be referred to a multi factors beside on the role of amino acids of protein, dietary fibers and antioxidants may play a good part in this action. Quazi et al. (32) reported that various dietary fibers at a $5 \%$ level in the diet significantly depressed serum total cholesterol and LDL plus VLDLcholesterol, liver cholesterol and total lipid. Gorinstein et al. (33) reported that other bioactive compounds in the fruit, for example, hesperidin and naringin, are powerful plasma lipid lowering agents, increase the plasma antioxidant activity. Citrus peel extracts, rich in pectins and flavonoids, cause lowering of cholesterol levels by modulating hepatic HMG-CoA levels, possibly by binding bile acids and increasing the turnover rate of blood and liver cholesterol (34).

Rats fed on hypercholesterolemic diet alone (positive control) record increased blood glucose concentrations (hyperglycemia). These results agree with Akiyama et al. (35), who found that serum glucose and insulin concentrations before and after glucose loading in the rat group received high-fat hypercaloric diet (360 kcal/kg body wt./day; $\mathrm{H}$ group) were significantly higher than those in the control diet (180 kcal/kg body wt./day; $\mathrm{C}$ group). Moreover, the insulin response relative to glucose response in the $\mathrm{H}$ group was significantly high compared to that in the $\mathrm{C}$ group, indicating the presence of insulin resistance. These results indicate that feeding of high-fat hypercaloric diet makes normal Wistar male adult rat obese associated with hyperlipidemia, hyperinsulinemia, and glucose intolerance.

The results showed that consuming OrAP at the two tested levels 10 and $20 \%$ as a source of fiber in food, markedly lowered the blood glucose levels in hypercholestero- 
lemic rats, and these findings indicate that OrAP can act as hypoglycemic agents, which in true could be attributed to the presence of the dietary fibers and polyphenols in OrAP as well as its antioxidant properties. De Escalada Pla et al. (36) confirmed that the soluble fiber components which include pectic polysaccharides, may through their viscosity enhancing and gel forming properties delay gastric emptying and possibly reduce absorption rate in small intestine, a feature that is particularly impotent to diabetes. Total protein was markedly increased with the addition of OrAP especially with $20 \%$, this increase may be due to the high crude protein content of OrAP.

The oxidative stress and the inflammatory processes in the endothelium have been shown to reduce reactive nitrous oxide (NO) dependent vasodilation. Well documented antioxidant and anti-inflammatory mechanisms regulated by Citrus flavonoids, such as increasing superoxide dismutase and catalase activities and protecting the plasma vitamin E (37) may well attenuate overproduction of oxygen reactive species in the vascular wall thereby restoring the imbalanced endothelial function. Among the few mechanistic studies on hypoglycemic effects of flavonoids, it has been shown that naringenin, similarly to other polyphenols significantly increased AMP kinase (AMPK) activity and glucose uptake in muscle cells and liver $(38,39)$. The hypoglycaemic activity of naringenin in vivo can be more complex and may depend on multilevel effects on lipid metabolism that lead to increased insulin sensitivity and glucose tolerance as shown in animal models of metabolic syndrome (40).

In our study, the positive control group recorded a significant decrease in hemoglobin, red blood cells (RBCs), hematocrit value (HCT \%) and white blood cells (WBCs) compared to the negative control group. On the other hand, the intake of OrAP with different concentrations prevents these pathogenic changes in the blood picture of rats. These results could be contributed to the improvement in iron absorption from rat's gut after consumption of OrAP due to its high content of ascorbic acid (41).

The present study indicated that the rats fed on hypercholesterolemic diet showed increased liver enzymes (AST, ALT and Alkaline phosphatase). The liver is a central organ for many physiological and biochemical process necessary for maintenance of life. Morphological alterations that occur in the liver affect many metabolic processes in the organism. Peroxide formation induced by hypercholesterolemia result in the release of some enzymes by interacting with cellular structure and function. Thus, the serum activities of cellular enzymes such as transaminases, alkaline phosphatase, and lactate dehydrogenase do increase. With the increase in cellular membrane permeability, intracellular fluid transfers onto intercellular space, resulting in muscle and liver cell degeneration (42).

Rats fed on 10 and $20 \%$ OrAP supplemented to hypercholesterolemic diet showed improved liver functions. AST and ALT levels act as indicators of liver functions, hence, restoration of normal levels of these enzymes indicates normal functions of liver. The reduction of AST and ALT close to their normal levels due to consumption of OrAP. Consequently, no significant differences were found among these groups and the negative control group. This effect is mainly related to the presence of natural soluble and insoluble dietary fiber, and through increasing the plasma antioxidant activity that have been reported to protect the liver against oxidative stress in rats. Flavonoids also attenuate lipopolysaccharide-induced hepatotoxicity, possibly by preventing the cytotoxic effects of NO and oxygen-free radicals (43).

Several studies showed that, some of the components of certain species of citrus fruit as Bergamot orange (BO), limonene and alpha-pinene, were shown to have hepatoprotective effects $(44,45,46)$. Therefore it is likely that BO has hepatoprotective effect. BO significantly reduced the serum ALT level while it did not affect the serum AST level (47).

The result of the present study also declared that OrAP especially at $20 \%$ level has a significant improvement effect on the kidney functions. This could be explained as consumption of food rich in dietary fibers stimulates the extrarenal route of nitrogen excretion. Younes et al. (48) found that indigestible carbohydrate/dietary fibers increased cecal weight and cecal blood flow, leading to accelerated diffusion of blood urea into the cecal lumen (by threefold), urea lysis to ammonia and protein synthesis by the microflora, and increased fecal excretion of nitrogen. Thus, reduce the role of kidney in the excretion of nitrogen and reduce blood urea concentration.

It could be noticed from the previous results that hypercholesterolemia increased organs weight especially (liver \& kidney) compared with the negative control, while their spleen and heart had no significant changes in their weights. However 20, 10\% OrAP supplemented to hypercholesterolemic treated groups significantly decreased the liver's weight compared with positive control. The affected liver weight by hypercholesterolemic diet is similar to those reported by Jemai et al. (49) who found that the liver/body weight ratio increased in rats fed cholesterol rich diet compared with those fed control diet. Although, some authors suggested that the consumption of WIFF as well as cellulose did not affect the weights of visceral organs of rats (9).

\section{Conclusion}

The present study demonstrates that the orange albedo powder had very pronounced hypocholesterolemic and hypoglycemic effects. It also serves to improve blood picture, liver function and kidney function in hypercholesterolemic rats. It could be a potential cholesterol-lowering ingredient in human diets, and offer industry an opportunity to develop new formulations of fiber-rich functional foods.

\section{References}

[1] Baigent, C., Keech, A., Kearney, P.M., Blackwell, L., Buck, 
G., Pollicino, C., Kirby, A., Sourjina, T., Peto, R., Collins, R. and Simes, R. (2005). Efficacy and safety of cholesterollowering treatment: prospective meta-analysis of data from 90,056 participants in 14 randomised trials of statins. Lancet, 366(9493):1267-78.

[2] Gielen, S., Sandri, M., Schuler, G. and Teupser, D. (2009). Risk factor management: antiatherogenic therapies. Eur. J. Cardiovasc Prev. Rehabil., 16(Suppl. 2): S29-36.

[3] Jones, P.H. (2008). Expert perspective: reducing cardiovascular risk in metabolic syndrome and Type 2 diabetes mellitus beyond low-density lipoprotein cholesterol lowering. Am. J. Cardiol., 102: 41L-47L.

[4] Alsheikh-Ali, A.A. and Karas, R.H. (2009). The relationship of statins to rhabdomyolysis, malignancy, and hepatic toxicity: evidence from clinical trials. Curr Atheroscler Rep., 11: 100-104.

[5] Joy, T.R. and Hegele, R.A. (2009). Narrative review: statinrelated myopathy. Ann. Intern. Med., 150(12): 858 - 868.

[6] Gil-Izquierdo, A., Gil, M.I. and Ferreres, F. (2002). Effect of processing techniques at industrial scale on orange juice antioxidant and beneficial health compounds. J. Agric. Food Chem., 50(18):5107-14.

[7] Fernández-Ginés, J., Navarro, C., Sendra, E., Sayas, M., Fernández-López, J. and Pérez-Álvarez, J. (2001). Colourimetric characterization of meat emulsion containing albedo. Vol II. pp. 162-163. In: Proceedings of 47th International Congress of Meat Science and Technology. Cracovia, Poland. $304 \mathrm{p}$.

[8] Pérez-Alvarez, J. A., Fernández-López, J., Sayas, E., Navarro, C. and Sendra, E. (2001). Effect of citrus fiber (albedo) incorporation in cooked pork sausages. In: Proceedings of International Food Technologists Annual Meeting. IFT Annual Meeting, New Orleans, Louisiana. 64 p.

[9] Chau, C.F., Huang, Y.L. and Lin, C.Y. (2004). Investigation of the cholesterol-lowering action of insoluble fibre derived from the peel of Citrus sinensis L. cv. Liucheung. Food Chem., 87:361- 366 .

[10] Kang, H.J., Chawla, S.P., Jo, C., Kwon, J.H. and Byun, M.W. (2006). Studies on the development of functional powder from citrus peel. Bioresearch Technology, 97(4): 614-620.

[11] Lario, Y., Sendra, E., García, J., Fuentes, C., Sayas, E., Fernández-López, J. and Pérez-Álvarez, J. (2004). Preparation of high dietary fiber powder from lemon juice by products. Innovative Food Science and Emerging Technologies, 5(1): 113-117.

[12] Fernández-López, J., Fernández-Ginés, J., Aleson, L., Sendra, E., Sayas, E. and Pérez-Álvarez, J. (2004). Application of functional citrus by-products to meat products. Trends in Food Science and Technology 15(3-4): 176-185.

[13] AOAC (2000). Method of analysis. Association of Official Agriculture Chemists. Washington D.C.USA, 17th ed.

[14] Fukushima, M., Takayama, Y., Habaguchi, T. and Nakano, M. (1997). Comparative hypocholesterolemic effects of capybara (Hydrochoerus hydrochaeris dabbenei) oil, horse oil and sardine oil in cholesterolfed rats. Lipid, 32(4): 391-395.

[15] Fossati, P. and Prencipe, L. (1982). The determination of triglyceride using enzymatic methods. Clin. Chem., 28:
2077-2080.

[16] Reitman, S. and Frankel, S. (1957). A colourimetric method for the determination of serum glutamic oxaloacetic and glutamic pyruvic transaminases. Am. J. Clin. Path., 28(56): $56-62$.

[17] Rec, G. (1972). Optimised standard colorimetric methods. J. Clin. Chem. and Clin. Biochem.,10: 182.

[18] Patton, C. J. and Crouch, S. R. (1977). Spectrophotmetric and kinetics investigations of the Berthelot reaction for the determination of ammonia. Analyti. Chem., 49: 464-469.

[19] Faulkner, N.R. and King, J.W. (1976). Fundamental of clinical chemistry (2nd ed.) Tietz, Sannders Philadelphia, 994998.

[20] Trinder, P. (1969). Determination of blood glucose using an oxidation peroxidase system with a non carsinogenic chromogene. Ann. Clin. Biochem., 6: 24.

[21] Henry, R. J. (1976). Clinical chemistry, Hoeber, New Yourk, 413.

[22] Doumas, B.T., Peters, T. Jr. (1997). Serum and urine albumin: a progress report on their measurement and clinical significance. Clin. Chem. Acta, 258(1): 3-20.

[23] International Committee for Standardization in Haematology. (1967). Recommendations for haemoglobinometry in human blood. Brit. J. Haemat., 13(4):71-75.

[24] Natt, M. P. and Herrick, C.A. (1952). A new blood count diluent for counting erythrocytes and leukocytes of the chicken. Poult. Sci., 31: 735-738.

[25] Campbell, T. W. (1995). Avian hematology and cytology, 2nd edition. Iowa State University Press, Ames, Iowa, 3-19.

[26] Fisher, R.A. (1970). Statistical method for research workers Edinburgh ed. 14, Oliver and Boyed, p. 140.

[27] Waller, R.A. and Duncan, D.B. (1969). Aboys rule for symmetric multiple comparison problem. An. State Assoc. J., 65: $1485-1503$.

[28] S.P.S.S. (1999). Statistical Package for the Social Sciences, version 10, SPSS, Inc., Chicago, Illinois.

[29] Chau, C.F. and Huang, Y.L. (2003). Comparison of the chemical composition and physicochemical properties of different fibers prepared from the peel of Citrus sinensis L. $\mathrm{Cv}$. Liucheng. Journal of Agricultural and Food Chemistry, 51(9): 2615-2618.

[30] Milagro, F.I., Campion, J. and Martinez, J.A. (2006). Weight gain induced by high-fat feeding involves increased liver oxidative stress. Obesity (Silver Spring), 14:1118-1123.

[31] Pratt, S.G. and Matthews, K. (2004). SuperFoods Rx: Fourteen Foods That Will Change Your Life. HarperCollins Publishers Inc., New York. 336 p.

[32] Quazi, S., Yokogoshi, H., Yoshida, A. (1983). Effect of dietary fiber on hypercholesterolemia induced by dietary PCB or cholesterol in rats. The Journal of nutrition, 113(6):110918.

[33] Gorinstein, S., Leontowicz, H., Leontowicz, M., Krzeminski, R., Gralak, M., Jastrzebski, Z., Park, Y.S., Jung, S.T., Kang, S.G. and Trakhtenberg, S. (2007). Effect of hesperidin and 
naringin on the plasma lipid profile and plasma antioxidant activity in rats fed a cholesterol-containing diet. Journal of the Science of Food and Agriculture, 87(7):1257-1262.

[34] Marounek, M., Volek, Z., Synytsya, A and Copíková, J. (2007). Effect of Pectin and Amidated Pectin on Cholesterol Homeostasis and Cecal Metabolism in Rats Fed a HighCholesterol Diet. Physiological Research, 56(4):433-42.

[35] Akiyama, T., Tachibana, I., Shirohara, H., Watanabe, N. and Otsuki, M. (1996). High-fat hypercaloric diet induces obesity, glucose intolerance and hyperlipidaemia in normal adult male Wistar rat. Diab. Res. Clin. Pract., 31(1-3): 27-35.

[36] De Escalada Pla, M.F., Ponce, N.M., Stortz, C.A., Gerschenson, L.N. and Rojas, A.M. (2007). Composition and functional properties of enriched fiber products obtained from pumpkin (Cucurbita moschata Duchesne ex Poiret). Lebensmittel-Wissenschaft \& Technologie, 40(7):1176-1185.

[37] Jeon, S.M., Bok, S.H., Jang, M.K., Lee, M.K., Nam, K.T., Park, Y.B., Rhee, S.J. and Choi, M.S. (2001). Antioxidative activity of naringin and lovastatin in high cholesterol-fed rabbits. Life Sci., 69(24): 2855-66.

[38] Hwang, J.T., Kwon, D.Y. and Yoon, S.H. (2009). AMPactivated protein kinase: a potential target for the diseases prevention by natural occurring polyphenols. N. Biotechnol., 26(1-2):17-22.

[39] Zygmunt, K., Faubert, B., MacNeil, J. and Tsiani, E. (2010). Naringenin, a citrus flavonoid, increases muscle cell glucose uptake via AMPK. Biochem. Biophys. Res. Commun., 398(2):178-83.

[40] Mulvihill, E.E., Allister, E.M., Sutherland, B.G., Telford, D.E., Sawyez, C.G., Edwards, J.Y., Markle, J.M., Hegele, R.A. and Huff, M.W. (2009). Naringenin prevents dyslipidemia, apolipoprotein $\mathrm{B}$ overproduction, and hyperinsulinemia in LDL receptor-null mice with diet-induced insulin resistance. Diabetes., 58(10): 2198-210.

[41] Shah, M., Griffin, I.J., Lifschitz, C.H. and Abrams, S.A. (2003). Effect of orange and apple juices on iron absorption in children. Arch Pediatr Adolesc Med. 157(12):1232-15236.
[42] Sudhahar, V., Kumar, S.A., Sudharsan, P.T., Varalakshmi, P. (2007). Protective effect of lupeol and its ester on cardiac abnormalities in experimental hypercholesterolemia. Vascul. Pharmacol. 46: 412-418.

[43] Ali, S., Prasad, R., Naime, M., Zafar, H., Mahmood, A., Routray, I., Yalniz, M., Ibrahim, H.B., Sahin, K. (2011). Dried peel fraction of Citrus sinensis partially reverses pathological changes in rat model of liver cirrhosis. Mediterr. J. Nutr. Metab., 4:57-67.

[44] Devi, K.P., Sreepriya, M., Balakrishna, K., Devaki, T. (2004). Protective effect of Premna tomentosa (L. Verbenaceae) extract on membrane-bound phosphatases and inorganic cations transport in acetaminophen-induced hepatotoxicity rats. Journal of Ethnopharmacology, 93: 371-375.

[45] Devi, K.P., Sreepriya, M., Balakrishna, K., Devaki, T. (2005). Protective effect of Premna tomentosa extract (L. verbanacae) on acetaminophen-induced mitochondrial dysfunction in rats. Molecular and Cellular Biochemistry, 272(1-2): 171-177.

[46] Özbek, H., Bayram, İ., Cengiz, N., Uğraş, S. (2005). Evaluation of Foeniculum vulgare compunds of Lethal Dose Levels and Hepatoprotective Effects.Turkish Pharmacological Society 18th National Pharmacology Congress, September, Izmir- Turkey, S40.

[47] Karaca, M., İlhanb, F., Altana, H., Himc, A., Tütüncüa, M. and Özbekd H. (2005). Evaluation of hepatoprotective activity of Bergamot orange in rats. Eastern J. of Med. 10(1-2): $1-4$.

[48] Younes, H., Garleb, K.A., Behr, S.R., Demigne', C., Remesy, C. (1998). Dietary fiber stimulates the extrarenal route of nitrogen excretion in partially nephrectomized rats . J. Nutr. Biochem., 9: 613-620.

[49] Jemai, H., Bouaziz, M., Fki, I., El Feki, A. and Sayadi, S. (2008). Hypolipidimic and antioxidant activities of oleuropein and its hydrolysis derivative-rich extracts from Chemlali olive leaves. Chemicobiological Interactions, 176(2-3): 88-98. 